\title{
Factors Causing Discretionary Auditor Change in the Insurance Industry: Evidence from Jordan
}

\author{
Submitted 05/03/21, $1^{\text {st }}$ revision 08/04/21, $2^{\text {nd }}$ revision 02/05/21, accepted 25/05/21
}

\section{Mansour Saaydah $^{1}$}

\begin{abstract}
:
Purpose: This study aims to examine the effect of several factors on the discretionary change of external auditors in the insurance industry in Jordan.

Design/Methodology/Approach: A discretionary change of an external auditor is the change that takes place before the end of the maximum allowed auditor tenure period (4-year in Jordan). The study sample comprises all Jordanian insurance companies with complete data for the period (2014-2018), and used a logistic regression model to test the hypotheses.

Findings: The study results revealed that modified audit opinion and change in firm's management significantly positively affect discretionary auditor change, while firm growth has a significant negative effect. The study recommends that the Jordanian Securities Commission issue instructions that prevent the firm new management from changing the auditor unnecessarily to work with a particular one with whom it might has a special relationship.

Practical Implications: The study claimed that due to the threat of discretionary change, the lack of auditor independence may lead to biased reports that may involve incorrect information and materially misstated financial statements that cover problems facing the firm and thus harm the company, industry, and the economy at large.

Originality/Value: The company incurs additional costs and time to select a new auditor and suffers the loss of experience and knowledge developed by the previous one, which may raise questions about the entity's policy. Therefore it is important to consider the solution proposed by this study.
\end{abstract}

Keywords: Discretionary auditor change, modified audit opinion, auditor reputation, change in firm management, firm growth, and firm insurance coverage.

JEL Classification: M41, M42.

Research Type: Research Paper.

\footnotetext{
${ }^{l}$ Prof. The University of Jordan, Department of Accounting, msaaydah@ju.edu.jo;
} 


\section{Introduction}

The final product of the Accounting system is the preparation of the financial statements that aim to provide helpful information for a variety of interested groups, such as stockholders, investors, creditors, managers, and tax authorities, in making economic decisions (Kieso et al., 2015). The value of the information in the financial reports increases if an independent (external) auditor audits it.

Auditing is defined as "the process of accumulating of relevant evidence about information, and evaluation of this evidence to determine the degree of corresponding between the information and established criteria, and then issue the audit report by an independent and competent person (independent auditor)" (Arens et al., 2017). The independent audit is performed by a third party, who has independence and neutrality, to provide an unbiased opinion about whether the financial statements are fair, free from material misstatements, and reflect the actual financial position of the entity.

The threat of auditor change may affect the auditor independence and then reduce the reliability and credibility of financial statements. If the auditor is not independent, she/he will not be able to improve the effectiveness of the audit process (Oladele, 2007). Some previous studies point to the following factors as causes for the change of auditor by the firm: Change in management, the need for extra auditing services, and the dissatisfaction with current audit services quality (Chow and Rice, 1982; Eischensher and Shields, 1983). Others point to the type of audit opinion received, financial distress, and audit firm reputation (Knapp and Elikai, 1988), while Ismail et al. (2008) found that the audit fees, financing activities, growth turnover, leverage, and the longevity of audit engagement are also important determinants of auditor change.

Jordanian regulations require that independent auditor tenure not exceed four years. That is, a company must change the independent auditor after four straight years of engagement. This change is classified as mandatory and is not the subject of this study. Instead, the discretionary or optional independent auditor change is the focus of this study, which is the change that takes place before finishing the maximum allowed period of engagement by the auditor.

This study aims to examine the effect of several factors on auditor change in the insurance industry in Jordan. These factors include modified audit opinion, audit firm reputation, change in firm's management, firm size, firm operations' complexity, firm growth, and firm insurance coverage, as possible reasons for the discretionary change of independent auditor in the insurance sector in Jordan. Auditor change is an important issue, especially if the change is discretionary, because auditor reports should reflect the reliability, credibility, and fairness of financial statements. Due to the threat of discretionary change, the lack of auditor independence may lead to biased reports that may involve incorrect information and materially misstated financial statements that cover problems facing the firm and thus harm the company, industry, and the economy at large. 
Although the firm changes the auditor optionally, it incurs additional costs and time to select a new one and suffers the loss of experience and knowledge developed by the previous one, which may raise questions about the entity's policy. Because there are only a few studies that examined the determinants of auditor change in Jordan, in general, and in the insurance industry in specific, this study intends to answer the following questions:

- Does the issuance of modified audit opinion significantly impact the discretionary auditor change in insurance companies listed in the Amman stock exchange?

- Does the firm audit reputation significantly impact the discretionary auditor change in insurance companies listed on the Amman stock exchange?

- Does the change in firm's management have a significant impact on the discretionary auditor change in insurance companies listed on the Amman stock exchange?

- Does the firm size significantly impact the discretionary auditor change in insurance companies listed on the Amman stock exchange?

- Does the firm operations' complexity significantly impact the discretionary auditor change in insurance companies listed on the Amman stock exchange?

- Does the growth in a firm's total assets significantly impact the discretionary auditor change in insurance companies listed in the Amman stock exchange?

- Does the firm's insurance coverage significantly impact the discretionary auditor change in insurance companies listed in the Amman stock exchange?

The importance of the study stems from drawing attention to the issue of discretionary auditor change in Jordan in general and in the insurance industry in specific via examining the factors leading to such an event. The importance of the study is also confirmed again because the auditor is a professional person who provides a report about the fairness of financial statements that reflects the firm's ability to continue as a going concern, its strengths, and weaknesses which reduces the risk of the firm information and help the users in making rational economic decisions. Therefore, identifying the factors that lead to discretionary auditor change is essential information, primarily to stockholders, investors, and corporate regulators.

The rest of the paper is organized as follows: Next section presents the literature review of the study and hypotheses development. Section three explains the statistical techniques applied in analysing the effect of several factors on auditor change. The results of the data analysis are presented in section four. Section five includes the conclusions and recommendations.

\section{Literature Review and Hypotheses Development}

An independent audit is performed by an independent auditor who examines the financial statements and the supporting financial documents to provide a report about the fairness of financial statements (being free from material misstatement due to 
fraud or error) and the compliance with International Financial Reporting Standards. This type of audit, which a third party performs, intends to eliminate any bias about the firm's financial positions, results of operations, and cash flows.

The first appearance of the audit offices in Jordan was in 1944, and the first law to regulate the practice of the profession (number 10) was 1961 (Alkhatib and Marji, 2012). Next, Jordan established the Jordanian Association of certified public accountants (JACPA) in 1987 to enhance Jordan's auditing and the accounting profession. In 2003 Jordan enacted law No. 3 to organize the profession of public accounting, which was renamed JACPA as Jordan Association for CPAs (JCPAs) and emphasized its role in organizing and enhancing the profession. The Jordanian Association of CPAs now consists of more than 600 members. It provides information on the profession, issues specialized journals, and provides training opportunities for CPAs to apply accounting and auditing standards properly.

Many Jordanian firms retain the same audit firm (for a very long time), substantial audit firms, due to the more confidence they have in them, although the rules call for a maximum of 4 years of auditor engagement tenure. Some studies on the audit quality indicated that if the company contracts with a big-four auditor, it will improve the audio quality compared with non-big four auditors (Hudaib and Cooke, 2005; Suyono et al., 2013; Khasharmeh, 2015). However, the long-term auditor firms' engagements can positively impact the audit quality. However, the more extended the relationships, the higher the potentials to create much more closeness between the auditor and the client, which may curb the auditor's independence, and eventually harms the audit quality and trustfulness (Al Rajabi and Warrad, 2017).

\subsection{Auditor Change}

Auditors ought to maintain independence, integrity, neutrality, honesty, and objectivity in holding their duties and responsibilities. Those ethical and professional aspects stress-free opinions about the fairness of the financial statements and being free from fraud and misconduct. Nowadays, especially after late multiple corporate scandals, doubts began to loom about auditors' independence and professional ethics (Kasih and Puspitasari, 2017).

It is known that companies may change their auditors voluntarily or mandatory. Mandatory change occurs to obey companies' law or Securities Commission regulations, while voluntary change is due to factors related to the firm itself or the auditor.

Auditor discretionary change is one of the essential topics that is drawing researcher's attention nowadays because of its effect on the neutrality and independence of the auditor. According to Jordan Corporate Law (\# 34 for 2017) and Securities Commission's regulations, the audit firm can provide its services to the same firm for a period of up to four consecutive years maximum. Subsequently, the change of auditor after four consecutive years is a standard or legal (mandatory) change, but the 
change before the end of the maximum tenure period (4 years) is considered intentional or discretionary change due to reasons that belong to the firm under audit or to the audit firm itself.

This study examines the following factors as possible reasons for auditor change in the insurance sector in Jordan. Modified audit opinion (or report), auditor reputation, change in firm's management, firm size, firm operations' complexity, firm growth, and firm insurance coverage. The followings are a brief explanation of each one of them:

A modified audit opinion can be issued if the requirements of unqualified (or clean) opinions have not been met. Adopting similar studies' approach, this study defines modified audit opinion as to any opinion other than the unqualified opinion, including qualified, adverse, and disclaimer of opinion. Several studies found that when the firm receives any modified audit opinion, it is more likely to change its auditor than when it receives an unqualified audit opinion (Chow and Rice, 1982; Krishnan, 1994; Geiger et al., 1998; Woo and Koh, 2001, Schauer, 2002; Lee et al., 2004, Gharibi and Geraeely, 2016, Susanto, 2018; Aloud, 2019).

Furthermore, Hussein (2008), Gharibi and Geraeely (2016), and Susanto (2018) indicated that the management might change its auditor to avoid a modified opinion because a modified opinion may reflect negatively on the management practices and adversely impact the price of firms securities. Meanwhile, AlAzhar (2015) indicated that the auditor change is not significantly affected by qualified audit opinion. Therefore, the following is the first hypothesis in the study.

H1: There is no significant effect of modified audit opinion on discretionary auditor change in listed insurance firms in ASE.

\subsection{Auditor Reputation}

Audit firm reputation may be an essential factor that affects auditor competency and independence and, therefore, discretionary change. There are two popular classifications of firm audit reputation. First, big-four firms (large audit firms) include Ernst and Young (E\&Y), Price Waterhouse Coopers (PWC), Klynveld peat Marwick Goerdeler (KPMG), and Deloitte \& Touch. Second, Non-big-four firms (all other audit firms). Many researchers relate auditor reputation to auditor size, especially in the form of big or non-big-four firms.

Woo and Koh (2001), Chadegani et al. (2011), Khasanah and Nahumury (2013), Nyakuwanika (2014), Khasharmeh (2015), and Kusrina and Yulivani (2016) found that audit firm size significantly affect auditor change, since the size of audit firm is related to the audit quality and reputation, and firms tend to change their auditor to big-four audit firms that can provide high-quality audit services, by using accurate, credible and high-quality information, while small audit firms are unable to fulfil the firm audit requirements. On the other hand, Suyono et al. (2013), AlRajabi and 
Warrad (2017), and Alroud (2019) found that the audit firm size does not affect auditor change. Therefore, the second hypothesis is:

H2: There is no significant effect of auditor reputation on discretionary auditor change in listed insurance firms in ASE.

\subsection{Change in Firm Management}

A change in firm management's key positions could be one of the critical factors that influence auditor change because the new management may prefer to change the auditor to work with a particular one who has a better relationship with her.

AlAzhar (2015), Kusrina and Yulivani (2016), found that new management (CEO or chairman of board of directors) is related to change in the policy of the company, which tends to switch its auditor to work with a particular one who can provide a better and high-quality audit services. Also, studies by Woo and Koh (2001), Nazri et al. (2012), Nyakuwanika (2014) concluded that a change in a firm's management leads to a change in auditor. The third hypothesis is:

H3: There is no significant effect of change in firm's management on discretionary auditor change in listed insurance firms in ASE.

\subsection{Firm Size}

Firm size ranges between small and large, and therefore, its audit need varies depending on its volume of transaction, business complexity, and specialization level. Several studies found that a small firm is more likely to receive modified audit opinions and then change its auditor (Krishnan, 1996; Copley and Douthett, 2002). However, Nasser et al. (2006), Nazri et al. (2012) found that large clients prefer to switch their auditor to big-four audit firms with more expertise to audit their financial statements rather than stay with small ones.

Similarly, Nyakuwanika (2014), Kusrina and Yulivani (2016), Gharibi and Geraeely (2016), Kasih and Puspitasari (2017) found that firm size has a significant relationship with auditor change since the large client has more complicated operations that require a large audit firm to audit its statements and reduce the agency cost. On the other hand Chadegani, et al. (2011) found an insignificant relationship between the auditee size and auditor change. The fourth hypothesis is:

H4: There is no significant effect of firm size on discretionary auditor change in listed insurance firms in ASE.

\subsection{Firm Operations' Complexity}

Woo and Koh (2001) defined operations complexity as the "number of subsidiaries the company owns or industrial sectors it operates in". They found that the complexity 
of the client is an essential factor that affects auditor change. At the same time, Boon et al. (2007) defined complexity as the difficulties of transactions or account balances that require additional effort and audit time.

Copley and Douthett (2002), Sankaraguruswamy and Whisenant (2004) indicated that the level of complexity is related to the firm's size and that large clients have a more complex operation than small ones. A large firm needs to switch its auditor to a large one with more and better expertise to audit their complex operations. Therefore, there is a significant effect of firm operations complexity on auditor change. Nazri et al. (2012) also found that client with higher complexity (a large number of client subsidiaries) is more likely to change its auditor. Gharibi and Geraeely (2016) indicated that a large company has a complicated operation required to be audited by a large audit firm to improve the audit quality and reduce the agency cost. The fifth hypothesis is:

H5: There is no significant effect of firm operations complexity on discretionary auditor change in listed insurance firms in ASE.

\subsection{Firm Growth}

Firm growth in terms of total assets or total revenues may call for auditor change, especially if the current auditor is a small one and cannot cope with the fast expansion of the firm under audit. Many researchers found that firm growth, particularly in total assets a vital cause for auditor change. This includes Woo and Koh (2001), Nasser et al. (2006), and Nazri et al. (2012). The sixth hypothesis is:

H6: There is no significant effect of firm growth on auditor change in listed insurance firms in ASE.

\subsection{Firm Insurance Coverage}

There are various insurance fields or types an insurance company may choose to cover; this includes primary fields and advanced or expanded fields. There are four types of insurance that most financial experts recommend to have, life, health, auto, and long-term disability. Expanded insurance fields, however, include, for example, property, travel, fire, theft, and a variety of liability insurance.

H7: There is no significant effect of the firm number of insurance coverage fields on discretionary auditor change in listed insurance firms in ASE.

\section{Data and Methodology}

\subsection{The Conceptual Model}

The current research examines the effect of the following variables on discretionary auditor change in the insurance industry in Jordan. Modified audit opinion, auditor 
reputation, change in firm management, firm size, firm operations complexity, firm growth, and firm insurance coverage.

Figure 1. Conceptual model of the study.

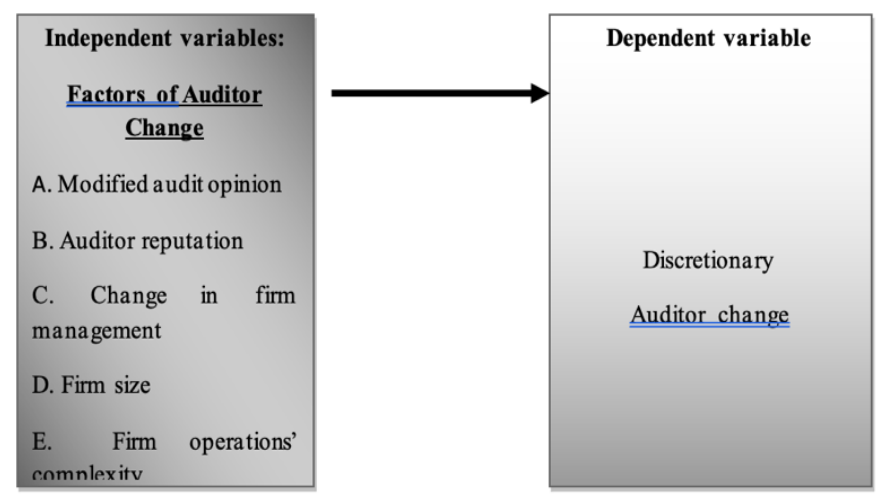

Source: Own creation.

The same conceptual model above is simulated in the below equation:

Achg $_{\mathrm{it}}=\beta_{0}+\beta_{1} \mathrm{MOD}_{\mathrm{it}}+\beta_{2}$ Arep $_{\mathrm{it}}+\beta_{3} \mathrm{FchgM}_{\mathrm{it}}+\beta_{4} \mathrm{Fsize}_{\mathrm{it}}+\beta_{5}$ Fcomp $_{\mathrm{it}}+\beta_{6}$ Fgrow $_{\mathrm{it}}+$ $\beta_{7}$ Fins $_{\text {it }}+\mathrm{e}_{\text {it }}$

where:

Achg $_{\text {it: }}$ Auditor discretionary change by firm $\mathrm{i}$ in year $\mathrm{t}$.

$\mathrm{MOD}_{\mathrm{it}}$ : modified audit opinion received by firm $\mathrm{i}$ in year $\mathrm{t}$.

Arep $_{\text {it }}$ : audit firm i reputation in year $\mathrm{t}$.

FchgM $_{\mathrm{it}}$ : change in firm i management in year $\mathrm{t}$.

Fzise $_{i t}$ : firm i size in year $t$.

Fcomp it: firm i operations' complexity in year t.

Fgrow ${ }_{\text {it: }}$ firm i growth in year $\mathrm{t}$.

Fins $C_{i t}$ : firm $i$ insurance coverage in year $t$.

$\mathrm{e}_{\mathrm{it}}$ : Error term.

\subsection{Study Population and Sample}

The study population and sample consist of all insurance companies listed in Amman Stock Exchange, during the period 2014-2019, who have complete data to run the logistic regression of the study. This process resulted in a sample of 21 companies (126 annual observations). Appendix A at the end of the study lists the names of these companies.

\subsection{Variables Measurements}

1- The Dependent Variable (Discretionary Auditor change):

Auditor change is defined as the event when the firm changes its independent 
(external) auditor. This variable is measured by a dummy variable that takes 1 if the firm chooses to change auditor before the end of the allowed maximum tenure (4 years in Jordan) and 0 if the firm did not change the auditor during the first four years of engagement. The maximum period of 4-year is determined based on Jordan corporate law (\#34 for 2017) and securities commission's regulations.

\section{2- Independent Variables:}

- Modified Audit Opinion: There are four types of audit opinions in general; unqualified, qualified, adverse and disclaimer. For the purpose of this study, unqualified opinion takes " 0 " and any opinion other than unqualified opinion (is considered modified opinion) and takes " 1 ". This includes qualified opinion, adverse opinion and disclaimer of opinion (Hudaib and Cooke, 2005; Chadegani, et al., 2011).

- Audit firm reputation: This variable is measured by a dummy variable, a bigfour firm is coded by "1", and a non-big four is coded by " 0 ". The big four auditing firms at the current time are: KPMG, PWC, E\&Y, and Deloitte \& Touch.

- Change in firm management (Chairman of the board of directors or the $C E O$ ): If the insurance company has a management change in any year (board chairman or the CEO) it is coded " 1 " and " 0 " otherwise.

- Firm size: The firm size is measured by the natural logarithm of total assets.

- Firm operations' complexity: firm operations complexity refers to the difficulties in classes of transactions or accounts' balances that require additional efforts, expertise, and audit time. This variable is measured by the number of subsidiaries and branches of the insurance company.

- Firm growth: Firm growth is measured by the percentage change in total assets.

- Firm insurance coverage: Firm insurance coverage is measured by the number of insurance fields covered by the company.

The Basic source of data for this study is the annual reports of listed insurance firms posted on the Amman Stock Exchange website, which include complete financial statements (financial position statement, income statement, etc.), auditor reports, and other information. This study's other data sources included relevant textbooks, periodicals, and sample insurance companies' websites.

\section{Data Analysis}

The study uses a logistic regression model to analyse data and test the hypotheses. Three critical assumptions need to be validated before the logistic regression tests are performed: the normality assumption, the non-multicollinearity, and the linearity (or no autocorrelation).

Normality Test: The normality test is used to examine if the study data is usually distributed. For this purpose, this research uses the Skewness and the Kurtosis tests. 
According to George and Mallery (2010) and West et al. (1995), if the absolute values of the skewness tests are less than (2) and the absolute values of the Kurtosis is less than 7 , then the data is considered normally distributed. Table 1 below shows that the Skewness and Kurtosis test results are within the allowed range (except for the dependent variable skewness value), which means that sample data is almost normally distributed.

Multicollinearity Test: Multicollinearity is a phenomenon that occurs when there are high correlations between two or more independent variables in a logistic regression model (Menard, 2000). To verify if there is a problem with Multicollinearity, the Variance inflation factors, and Tolerance tests are used.

Variance inflation factors (VIF): If the VIF value of the variable is $\leq 10$, then there is no multicollinearity, but if it is greater than 10, the regression coefficients are poorly determined due to multicollinearity (Field, 2013). Table 2 shows no multicollinearity problem since all VIF values are less than the accepted cut-off point (10) for all variables.

Table 1. Skewness and Kurtosis Tests

\begin{tabular}{|c|c|c|c|c|}
\hline \multirow{2}{*}{ Study variables } & \multicolumn{2}{|c|}{ Skewness } & \multicolumn{2}{c|}{ Kurtosis } \\
\cline { 2 - 5 } & Statistic & Std. Error & Statistic & Std. Error \\
\hline Auditor change & 2.189 & 0.236 & 2.844 & 0.467 \\
\hline Modified audit opinion & 1.016 & 0.236 & -0.988 & 0.467 \\
\hline Audit reputation & -0.058 & 0.236 & -2.036 & 0.467 \\
\hline Change in firm management & 1.862 & 0.236 & 1.497 & 0.467 \\
\hline Firm size & 0.206 & 0.216 & 0.534 & 0.428 \\
\hline Firm operations complexity & 0.758 & 0.241 & -0.061 & 0.478 \\
\hline Firm growth & 0.003 & 0.236 & -0.415 & 0.467 \\
\hline Firm insurance coverage & 0.697 & 0.226 & -0.042 & 0.449 \\
\hline
\end{tabular}

Source: Own study.

Tolerance: Tolerance is another test used to detect multicollinearity, as statisticians suggest that variables involved in any relationship need to have small tolerance. The value of tolerance needs to be less than 1 (George and Mallery, 2010). Table 2 shows that all tolerance values are less than one each.

Autocorrelation Test: The last assumption of the regression is the independent observations. The autocorrelation test is used to explore the serial correlation among residuals from the regression analysis. The Durbin-Watson test is used here. The optimal cut-off for the Durbin-Watson test ranges from 1.5 to 2.5 (Hill and Flack, 1987). Hence, Table 3 shows the autocorrelation test results:

Table 3 shows that the Durbin-Watson values fall within the acceptable range (1.5 and 2.5). This means there is no autocorrelation problem in the residuals for all variables. 
Table 2. Multicollinearity Test

\begin{tabular}{|c|c|c|c|}
\hline & Variable & VIF & Tolerance \\
\hline$(1)$. & Modified audit opinion & 1.411 & 0.769 \\
\hline$(2)$. & Auditor reputation & 1.541 & 0.649 \\
\hline (3). & Change in firm management & 1.241 & 0.806 \\
\hline$(4)$. & Firm size & 1.904 & 0.525 \\
\hline (5). & Firm operations complexity & 1.306 & 0.766 \\
\hline (6). & Firm growth & 1.106 & 0.904 \\
\hline (7). & Firm insurance coverage & 1.235 & 0.809 \\
\hline
\end{tabular}

Source: Own creation.

Table 3. Autocorrelation Test

\begin{tabular}{|c|c|c|}
\hline Dependent Variable & Model & Durbin - Watson values \\
\hline Modified audit opinion & 1 & 1.791 \\
\hline Audit firm size & 2 & 1.811 \\
\hline Change in auditee management & 3 & 1.812 \\
\hline Auditee Financial condition & 4 & 1.806 \\
\hline Size of auditee & 5 & 1.817 \\
\hline Audit fees & 6 & 1.813 \\
\hline Auditee complexity & 7 & 1.803 \\
\hline Auditee Ownership concentration & 8 & 1.809 \\
\hline
\end{tabular}

Source: Own creation.

\subsection{Descriptive Statistics}

The descriptive statistics describe the study data, including the mean, the maximum, the minimum, and the standard deviations. Descriptive statistics give signs about the sample firms. For example, Table 4 shows that the mean value of auditor change is 0.13 , with a standard deviation of 0.342 , meaning that $13 \%$ of sample firms changed their auditors during 2014-2019, indicating a minority of sampled insurance firms chose to change auditors. For the modified audit opinion, the mean value is 0.28 with a standard deviation of 0.449 , which means that more than $1 / 4$ of sampled firms could not obtain clean opinions. The means of firm audit reputation is 0.51 with a standard deviation of 0.502, representing that Big-4 audit firms audit more than one-half of sampled firms. The table also shows that $16 \%$ of firms have changed their management over the study period with a standard deviation of 0.370 .

Regarding firm size (natural logarithm of total assets), the average is 10.282 with a standard deviation of 0.666 . The firm operations complexity has a mean value of 4.25 with a standards deviation of 1.982 , which indicates some high complexity among study firms. The firm average growth rate is $4.387 \%$, with a standard deviation of $8.173 \%$, a relatively low growth rate. The firm average insurance coverage is 7.11 types of insurance with a standard deviation of 2.006 .

Finally, most standard deviation values are relatively high (almost twice the averages or more) of some variables, including Auditor change, modified audit opinion, change 
in firm management, and firm growth. At the same time, the standard deviations of auditor reputation, firm size, firm operations' complexity, and firm insurance coverage are reasonable (less than the means).

Table 4. Descriptive Statistics

\begin{tabular}{|c|c|c|c|c|}
\hline & Minimum & Maximum & Mean & Std. Deviation \\
\hline Auditor change & 0 & 1 & 0.13 & 0.342 \\
\hline Modified audit opinion & 0 & 1 & 0.28 & 0.449 \\
\hline Auditor reputation & 0 & 1 & 0.51 & 0.502 \\
\hline Change in firm management & 0 & 1 & 0.16 & 0.370 \\
\hline Firm size & 8.89 & 11.61 & 10.282 & 0.666 \\
\hline Firm operations' complexity & 2 & 9 & 4.25 & 1.982 \\
\hline Firm growth (\%) & -14.96 & 25.04 & 4.387 & 8.173 \\
\hline Firm insurance coverage & 4 & 12 & 7.11 & 2.006 \\
\hline
\end{tabular}

Source: Own creation.

\subsection{Pearson Correlation}

The results of the Pearson analysis are shown in Table 5. The Table shows that auditor change has significant positive correlations with change in firm management $(\mathrm{r}=$ 0.512 , sig. at 0.01$)$ and modified audit opinion $(r=0.447$, sig. at 0.01$)$. The other high correlations shown in the table are between auditor reputation and firm size $(r=0.567$, sig. at 0.01) and between modified audit opinion and change in firm management ( $\mathrm{r}$ $=0.365$, sig at 0.01 ), and between operating complexity and firm insurance coverage $(r=0.341$, sig. at 0.01$)$ and between modified audit opinion and firm size $(r=-0.279$, sig at 0.01 ) although the latter correlation is negative. A negative correlation means the increase in the independent variable leads to a decrease in auditor change. In our case, the larger the firm size, the less likely the firm will obtain a modified audit opinion.

Table 5. Pearson Correlation

\begin{tabular}{|c|c|c|c|c|c|c|c|c|}
\hline Variable & $\begin{array}{c}\text { Auditor } \\
\text { change }\end{array}$ & $\begin{array}{c}\text { Modified } \\
\text { audit } \\
\text { opinion }\end{array}$ & $\begin{array}{c}\text { Auditor } \\
\text { reputation }\end{array}$ & $\begin{array}{c}\text { Change } \\
\text { in firm } \\
\text { manag- } \\
\text { ement }\end{array}$ & Firm Size & $\begin{array}{c}\text { Firm op. } \\
\text { complex }\end{array}$ & $\begin{array}{c}\text { Firm } \\
\text { growt } \\
\text { h }\end{array}$ & $\begin{array}{c}\text { Firm } \\
\text { Insur } \\
\text { ance } \\
\text { cover } \\
\text { age }\end{array}$ \\
\hline Auditor change & $\mathbf{1}$ & & & & & & & \\
\hline Mod. audit opinion & $\mathbf{0 . 4 4 7}$ & $\mathbf{1}$ & & & & & & \\
\hline Auditor reputation & $\mathbf{- 0 . 0 1 1}$ & $\mathbf{- 0 . 0 8 2}$ & $\mathbf{1}$ & & & & & \\
\hline $\begin{array}{c}\text { Change in firm } \\
\text { management }\end{array}$ & $\mathbf{0 . 5 1 2 * *}$ & $\mathbf{0 . 3 6 5 *}$ & $\mathbf{0 . 0 1 3}$ & $\mathbf{1}$ & & & & \\
\hline Firm Size & $\mathbf{0 . 0 1 2}$ & $\mathbf{- 0 . 2 7 9} * *$ & $\mathbf{0 . 5 6 7 *}$ & $\mathbf{0 . 0 4 2}$ & $\mathbf{1}$ & & & \\
\hline $\begin{array}{c}\text { Firm operations } \\
\text { complexity }\end{array}$ & $\mathbf{0 . 0 8 7}$ & $\mathbf{- 0 . 0 3 4}$ & $\mathbf{0 . 0 8 3}$ & $\mathbf{0 . 0 2 8}$ & $\mathbf{0 . 2 4 0 *}$ & $\mathbf{1}$ & & \\
\hline Firm growth & $\mathbf{- 0 . 1 0 4}$ & $\mathbf{- 0 . 0 6 1}$ & $\mathbf{0 . 0 4 7}$ & $\mathbf{0 . 1 0 1}$ & $\mathbf{0 . 2 1 5 *}$ & $\mathbf{0 . 0 3 2}$ & $\mathbf{1}$ & \\
\hline $\begin{array}{c}\text { Firm insurance } \\
\text { coverage }\end{array}$ & $\mathbf{0 . 0 5 6}$ & $\mathbf{- 0 . 0 7 9}$ & $\mathbf{- 0 . 0 3 8}$ & $\mathbf{- 0 . 0 3 7}$ & $\mathbf{- 0 . 0 1 7}$ & $\mathbf{0 . 3 4 1 * *}$ & $\mathbf{0 . 1 6 9}$ & $\mathbf{1}$ \\
\hline
\end{tabular}

Note: $*$ Correlation is significant at 0.05 level (2-tailed)** Correlation is significant at 0.01 level (2-tailed)

Source: Own creation. 


\subsection{Hypotheses Testing}

To test the research hypotheses, this study used the logistic regression model to analyse the data. Table 6 reports the logistic regression results:

- The coefficient of determination (Nagelkerke $\mathrm{R}^{2}$ ) measures the variations in the dependent variable explained by changes in the independent variables. $\mathrm{R}^{2}(0.546)$ value is good, indicating that the independent variables explain a considerable amount (more than one-half) of the variations of auditor change. These better results compared to some similar studies obtained low $\mathrm{R}^{2}$ (Teh et al., 2016, $\mathrm{R}^{2}$ around 0.05; Kasih and Puspitasari 2017, $\mathrm{R}^{2}=0.01$, and Aloud, 2019, $\mathrm{R}^{2}=0.07$ ).

- The study results indicate a significant positive impact on the auditor change by the Modified audit opinion (sig. at 0.020) and the Change in firm management (sig. at 0.002, and significant negative impact by the firm growth (sig. at 0.094). The rest of the variables have no significant impact on auditor change.

- The results also show that the impact value $(\beta)$ of modified audit opinion on auditor change is (2.487), and Change in firm management is (3.194), and the firm growth is $(-0.111)$. These results indicate that when modified audit opinion or Change in firm management increase by one unit, the auditor change is expected to increase by their beta values. Similarly, when firm growth increases by one unit, auditor changes are expected to decrease by the beta value of firm growth. Also, for the firm size $(b=0.963)$ and firm insurance coverage $(b=0.283)$ have positive signs, indicating that when those independent variables increase by one unit each, the auditor change is expected to increase by their beta values, but these changes are insignificant. However, auditor reputation is expected to lead to more minor Changes in auditor change but insignificant.

- In light of the above results, the following null hypotheses are rejected (and the alternative hypotheses are accepted).

$H_{0,1}:$ There is no significant effect of modified audit opinion on discretionary auditor change in listed insurance firms in ASE.

$H_{0,3}$ : There is no significant effect of change in firm Management on auditor discretionary change in listed insurance firms in ASE.

$H_{0,7}$ : There is no significant effect of firm growth on auditor discretionary change in listed insurance firms in ASE.

Table 6. Logistic Regression Analysis

Model Summary
\begin{tabular}{|c|c|c|c|c|}
\hline Step & -2 Log likelihood & $\begin{array}{c}\text { Cox \& Snell R } \\
\text { Square }\end{array}$ & $\begin{array}{c}\text { Nagelkerke R } \\
\text { Square }\end{array}$ & Overall (sig) \\
\hline 1 & $38.934^{\mathrm{a}}$ & .297 & 0.546 & 0.000 \\
\hline
\end{tabular}

*a. Estimation terminated at iteration number 7 because parameter estimates changed by less than 0.001 .

Variables in the Equation 


\begin{tabular}{|l|c|c|c|c|c|c|}
\hline & B & S.E. & Wald & D. f. & Sig. & Exp. (B) \\
\hline Modified audit opinion & 2.487 & 1.070 & 5.402 & 1 & 0.020 & 12.029 \\
Audit reputation & - & 1.299 & .066 & 1 & 0.797 & 0.716 \\
& .0 .334 & & & & & \\
Change in firm management & 3.194 & .1051 & 9.236 & 1 & 0.002 & 24.386 \\
Firm Size & 0.963 & 0.991 & 0.946 & 1 & 0.331 & 2.620 \\
Firm operations complexity & 0.004 & 0.244 & .000 & 1 & 0.988 & 1.004 \\
Firm growth & -0.111 & 0.060 & 2.801 & 1 & 0.094 & 0.895 \\
Firm insurance coverage & 0.283 & 0.294 & 0.932 & 1 & 0.334 & 1.328 \\
Constant & - & & & & & \\
& 15.375 & 10.268 & 2.242 & 1 & 0.134 & 0.000 \\
\hline
\end{tabular}

a. Variable(s) entered on step 1: modified audit opinion, audit firm size, change in auditee management, auditee financial condition, auditee size, audit fees, auditee complexity, and auditee ownership concentration.

Source: Own creation.

However, the other null hypotheses which are not rejected were:

$H_{0,2}:$ There is no significant effect of audit reputation on auditor discretionary change in listed insurance firms in ASE.

$H_{0,5}$ : There is no significant effect of firm size on auditor discretionary change in listed insurance firms in ASE.

$H_{0,6}$ : There is no significant effect of firm operations complexity on auditor discretionary change in listed insurance firms in ASE.

$H_{0,8}$ : There is no significant effect of firm insurance coverage on auditor discretionary change in listed insurance firms in ASE.

\subsection{Discussion of Results}

The current study provides some evidence on the impact of several factors on auditor change in the insurance sector in Jordan. The study results show that there is a significant positive effect of modified audit opinion on auditor change; this result means that when the firm receives a qualified audit opinion or any other type of modified opinion, it is more likely to change its auditor than when it receives an unqualified audit opinion. This factor is not too small based on study data since more than $1 / 4(28 \%)$ of insurance firms have received modified opinions during the study period (2014-2019). Such audit opinion is issued when the requirements of an unqualified opinion are not met. This result is consistent with Hudaib and Cooke (2005), Hussein (2008), Gharibi and Geraeely (2016), and Susanto (2018), and Alroud (2019). On the other hand, this result is not consistent with Chadegani et al. (2011), Nazri et al. (2012) who have found no significant relationship between modified audit opinion and auditor change.

The study results also show that the change in firm management has a significant positive effect on auditor change. This means that when firm management is changed, 
the new management will likely change the firm's auditor. The reason for this change is probably the tendency of new management to work with a particular auditor who has a relationship with it. This result is consistent with Hussein (2008); Nazri et al. (2012); Nyakuwanika, (2014); Kusrinaand Yulivani (2016) and Alroud, (2019). However, it is not consistent with Khasharmeh (2015), Khasanah and Nahumury (2013), Chadegani et al. (2011), who found no impact from the change in auditee management on auditor change.

Furthermore, the results show that the firm growth has a significant negative effect on auditor change. This result agrees with that of Woo and Koh (2001), Nasser et al. (2006), and Nazri et al. (2012). The study also shows the following results:

Insignificant positive effect of auditor reputation on auditor changes consistent with Gharibi and Geraeely (2016), AlRajabi and Warrad (2017). However, not consistent with Hussein (2008), Khasanah and Nahumury (2013), Khasharmeh (2015), who found a significant relationship between these variables.

There is also an insignificant negative effect of firm size on auditor change. This result agrees with Kusrina and Yulivani (2016) and Alroad (2019) but does not agree with Nazri et al. (2012), and Kasih and Puspitasari (2017).

Also, there is an insignificant negative effect of firm operations' complexity on auditor change. This result is consistent with Boon et al. (2007) and Alroud (2019) but is inconsistent with Copley and Douthett (2002), Sankaraguruswamy and Whisenant (2004), and Nazri et al. (2012). The final result shows that there is an insignificant positive impact of firm insurance coverage on auditor change.

\section{Conclusions and Recommendations}

Auditor change is essential because an auditor plays a vital role in promoting the fairness and credibility of financial statements by issuing a neutral opinion about the results of operations, financial position, and cash flows of a company, which various parties depend on in decision-making. Study results showed that $13 \%$ of insurance companies in Jordan had made discretionary auditor change over the period 20142019; these companies changed their auditors before the maximum tenure period allowed in Jordan (4 years). Most insurance companies were audited by big- four audit firms, including Ernst and Young, Price Waterhouse Coopers, Klynveld peat Marwick Goerdeler, Deloitte, and Touch. Many insurance companies received unqualified audit opinions, while $21 \%$ received modified audit opinions during the study period (2014-2019). It appeared from this study results that management changes (chairman of the board of director or CEO) in Jordanian companies are relatively low (16\%), average total assets growth is $4.387 \%$ is relatively low.

- Small auditors should enroll themselves in professional training courses to enhance their technical skills and improve their audit capabilities to provide a high-quality audit services that lead to avoiding discretionary auditor 
change from small to big-four audit firm.

- Jordan Securities Commission and/or Jordanian association of certified public accountants should issue instructions that prevent the company's new management from changing the auditor to work with a particular one who probably has a personal relationship with it.

- Jordan Securities Commission and/or Jordanian association of certified public accountants should issue instructions that give the auditors the right to discuss their discretionary change decisions and explain the reasons for it.

Further studies:

- Examine the effect of new variables on Auditor discretionary change in insurance companies and other sectors such as audit time lag, the level of competition between audit firms, the opportunity for practicing earnings management, and others.

- Use some control variables to strengthen the logistic regression power and its results.

\section{References:}

AlAzhar, L. 2015. Influence of Financial Distress, Management Turnover and Audit Opinion to Auditor Change (Empirical Study on Manufacturing Companies Listed on the BEI during 2011-2013 Period). Research Journal of Finance and Accounting, 6(24), 120-126.

Alkhatib, K., Marji, Q. 2012. Audit reports timeliness: Empirical evidence from Jordan. Procedia-Social and Behavioral Sciences, 62, 1342-1349.

AlRajabi, T., Warrad, L.H. 2017. Factors Affecting Audit Firms' Rotation: Jordanian Case. European Journal of Economics, Finance and Administrative Sciences, 6-24.

Alroud, Lubna. 2019. Determinants of auditor switching in Jordan: An empirical study, unpublished master's thesis in the accounting department in the University of Jordan.

Arens, A., Elder, D., Beasley, S. 2017. Auditing and Assurance Services, 16th edition. Boston: Prentice Hall.

Boon, K., McKinnon, J., Ross, P. 2007. Factors Associated with the Choice of a Quality Auditor when Audit Tendering is Compulsory. Accounting and Business Research, 31(2), 133-144.

Chadegani, A., Muhammaddun Mohamed, Z., Jari, A. 2011. The determinant factors of auditor switch among companies listed on Tehran Stock Exchange. International Research Journal of Finance and Economics, 80(1), 158-169.

Chow, C.W., Rice, S.J. 1982. Qualified audit opinions and auditor change. Accounting Review, 57(2), 326-335.

Chung D.Y., Lindsay W.D. 1988. The pricing of audit services: the Canadian perspective. Contemporary Accounting Research, 5(1), 19-46.

Copley, P.A., Douthett, E.B. 2002. The association between auditor choice, ownership retained, and earnings disclosure by firms making initial public offerings. Contemporary Accounting Research, 19(1), 49-75.

DeAngelo, L. 1982. Mandated successful efforts and auditor choice. Journal of Accounting and Economics, 4(3), 171-203.

DeFond, M. L., Wong, T.J., Li, S. 2000. The impact of improved auditor independence on 
audit market concentration in China. Journal of Accounting and Economics, 28(3), 269-305.

Eichenseher, J.W., Hagigi, M., Shields, D. 1989. Market reaction to auditor changes by OTC companies. Auditing-A Journal of Practice and theory, 9(1), 29-40.

Field, A. 2013. Discovering statistics using IBM SPSS statistics. Fourth Ed. University of Sussex, UK.

Firth, M. 1997. The provision of non-audit services and the pricing of audit fees. Journal of Business Finance and Accounting, 24(3), 511-525.

Francis, J.R. 1984. The effect of audit firm size on audit prices: a study of the Australian market. Journal of Accounting and Economics, 6(2), 133-151.

Francis, J.R., Simon, D.T. 1987. A test of audit pricing in a small-client segment of the US market. The Accounting Review, 62(1), 145-157.

Francis, J.R., Wilson, E.R. 1988. Auditor Changes: A Joint Test of Theories Relating to Agency Costs and Auditor Differentiation. The Accounting Review, 63(4), 663682.

Geiger, M., Raghunandan, K., Rama, D.V. 1998. Costs Associated with Going-Concern Modified Audit Opinions: An Analysis of Auditor Changes, Subsequent Opinions, and Client Failures. Advances in Accounting, 16(1), 117-139.

George, D., Mallery, P. 2010. SPSS for Windows step by step. A simple study guide and reference, Boston, Allyn and Bacon.

Gharibi, A.K., Geraeely, M.S. 2016. Investigating the effective factors on changing auditor: evidence of Iranian firms. Problems and Perspectives in Management, 14(3), 401-406.

Gul, F.A 1989. Banker's perceptions of factors affecting auditor independence. Accounting, Auditing and Accountability Journal, 2(3), 40-51.

Gul, F.A. 1992. A note on audit qualification and switches: some further evidence from a small sample study. Journal of international accounting auditing and taxation, 1(1), 111-120.

Hill, R.J., Flack, H.D. 1987. The use of the Durbin-Watson statistic in Rietveld analysis. Journal of Applied Crystallography, 20(5), 356-361.

Hudaib, M., Cooke, T.E. 2005. The impact of managing director changes and financial distress on audit qualification and auditor change. Journal of Business Finance \& Accounting, 32(9-10), 1703-1739.

Hussein, H. 2008. Analysing the factors affecting the change of external auditors in Iraqi public companies. Baghdad College Journal for Economic Sciences, 16, 248-276 (In Arabic).

Ismail, S., Aliahmed, H.J. Nassir, A.M., Hamid, M.A.A. 2008. Why Malaysian second board companies switch auditors: evidence of Bursa Malaysia. International Research Journal of Finance and Economics, 13(13), 123-130.

Jordanian Association of Certified Public Accountants. Retrieved from: http:// jacpa.org.jo.

Jensen, M.C., Meckling, W.H. 1976. Theory of the firm: Managerial Behavior. Journal of Financial Economics, 305-360.

Kasih, M., Puspitasari, E. 2017. Auditor's change factors: the analysis of audit delay, client size, and audit committee changes. Parahyangan International Accounting and Business Conference, 589-607.

Kassem, R., Higson, A.W. 2016. External auditors and corporate corruption: Implications for external audit regulators. Current Issues in Auditing, 10(1), 1-10.

Kenneth, S.B., Krishnagopal, M. 1985. Auditor switches by failing firms. Accounting Review, 60(2), 248-261.

Khasanah, I., Nahumury, J. 2013. The factors affecting auditor change in manufacturing 
companies listed in Indonesia Stock Exchange (BEI). The Indonesian

Accounting Review, 3(2), 203-212.

Khasharmeh, H.A. 2015. Determinants of Auditor Change in Bahraini's Listed Companies An Empirical Study. European Journal of Accounting, Auditing and Finance Research, 3(11), 73-99.

Kieso, D.E. Weygandt, J.J., Warfield, T.D. 2015. Intermediate Accounting, $13^{\text {th }}$ Ed. Hoboken, N.J., Wiley.

Kimeli, E.K. 2016. Determinants of Audit Fees Pricing: Evidence from Nairobi Securities Exchange (NSE). International Journal of Research in Business Studies and Management, 3(1), 23-35.

Knapp, M.C., Elikai, F. 1988. Auditor Changes: A Note on the Policy Implications of Recent Analytical and Empirical Research. Journal of Accounting, Auditing and Finance, 3(1), 78-86.

Krishnan, J. 1994. Auditor Change and Conservatism. The Accounting Review, 69(1), 200215.

Krishnan, J. 1996. The Role of Economic Trade-Offs in the Audit Opinion Decision: An Empirical Analysis. Journal of Accounting Auditing and Finance, 11(4), 565586.

Kusrina, B.L., Yulivani, P. 2016. Analysis of factors affecting auditor change. Advances in Global Business Research, 13(1), 2463-2470.

Lee, H.Y., Mande, V., Ortman, R. 2004. The Effect of Audit Committee and Board of Director Independence on Auditor Resignation. Auditing: A Journal of Practice \& Theory, 23(2), 131-146.

Menard, S. 2000. Coefficients of determination for multiple logistic regression analysis. The American Statistician, 54(1), 17-24.

Nasser, A.T., Wahid, A.E., Nazri, S.N., Hudaib, M. 2006. Auditor-client relationship: the case of audit tenure and auditor change in Malaysia. Managerial Auditing Journal, 21(7), 724-737.

Nazri, S., Smith, M., Ismail, Z. 2012. Factors influencing auditor change: evidence from Malaysia. Asian Review of Accounting, 20(3), 222-240.

Nyakuwanika, M. 2014. Why companies change auditors in Zimbabwe? (2003-2013). Research Journal of Finance and Accounting, 5(5), 171-181.

Oladele, K.O. 2007. Auditor's Independence and Accountability in Nigeria Public enterprises: A Case of the Nigerian Ports Authority. KASU Journal of Management Sciences, 1(4).

Peel, M.J., Roberts, R. 2003. Audit fee determinants and auditor premiums: Evidence from the micro-firm sub-market. Accounting and Business Research, 33(3), 207-233.

Sankaraguruswamy, S., Whisenant, J.S. 2004. An empirical analysis of voluntarily supplied client-auditor realignment reasons. Auditing: A Journal of Practice and Theory, 23(1), 107-121.

Schauer, P.C. 2002. The Effects of Industry Specialization on Audit Quality: An Examination Using Bid-Ask Spreads. Journal of Accounting and Financial Research, 10(1), 67-86.

Schwartz, K.B., Menon, K. 1988. Auditor switches by failing firms. The Accounting Review, 60(2), 248-261.

Simunic, D.A. 1980. The pricing of audit services: Theory and evidence. Journal of Accounting Research, 161-190.

Susanto, Y.K. 2018. Auditor change: management turnover, qualified opinion, audit delay, financial distress. International Journal of Business, Economics and Law, 15(5), 125-132. 
Suyono, E., Yi, F., Riswan, M.M. 2013. Determinant factors affecting the auditor change: An Indonesian case. Global Review of Accounting and Finance, 4(2), 103-116.

Teh, B.H., Ong, T.S., Adedeji, B.S., Ng, S.H. 2016. An empirical study of auditors changes corporate governance and financial performances of Malaysian public listed companies (PLCs). Journal Pengurusan, 47, 43-53.

Weiner, J. 2012. Auditor Size vs Audit Quality: An Analysis of Auditor Switches. Thesis of Honors at Honors College, University of Houston.

West, S.G., Finch, J.F., Curran, P.J. 1995. Structural Equation Models with non-normal Variables: Problems and remedies. In: R.H. Hoyle (Ed.), Structural equation modelling: Concepts, issues, and applications, 56-75. Sage Publications, Inc.

Willenborg, M. 1999. Empirical analysis of the economic demand for auditing in the initial public offerings market. Journal of Accounting Research, 37(1), 225-239.

Willekens, M., Achmadi, C. 2003. Pricing and supplier concentration in the private client segment of the audit market: Market power or competition? The International Journal of Accounting, 38(4), 431-455.

Woo, E.S., Koh, H.C. 2001. Factors associated with auditor changes: a Singapore study. Accounting and Business Research, 31(2), 133-144.

\section{Appendix A}

\begin{tabular}{|l|}
\hline \multicolumn{1}{|c|}{ Name of sample insurance firms } \\
\hline Middle East Insurance \\
\hline Al-Nisr AL-Arabi insurance \\
\hline Jordanian Insurance \\
\hline Arab Insurance - Jordan \\
\hline Delta Insurance \\
\hline Jerusalem Insurance \\
\hline The United Insurance \\
\hline Jordan French Insurance \\
\hline AL-Manara Insurance PLC \\
\hline Arab Orient Insurance \\
\hline Arab Life \& Accident Insurance \\
\hline Philadelphia Insurance \\
\hline Arab Union International Insurance \\
\hline National Insurance \\
\hline Jordan International Insurance \\
\hline Arab European Insurance Group \\
\hline Islamic Insurance \\
\hline Arab guarantors for insurance \\
\hline Arab Jordanian Insurance Group \\
\hline Mediterranean and Gulf for Insurance \\
\hline The First for Insurance \\
\hline
\end{tabular}

